Какихъ либо побочныхъ непріятвыхъ явленій при ивъекдіяхъ авторъ не наблюдалъ, кромь развъ въ несколькихъ случаяхъ появленія легкаго озноба съ кратковременнымъ небольпимъ повытеніещъ температуры.

Ф. Кюнъ.

17. Th. Opie. A report of three supra-vaginal hysterectomies and similar cases treated by electrolysis. (Journ. of the Amcr. Med. Assoc. July 11, 1891). Три случая надвлагалищнаго вырђзыванія матки и подобные же случаи, пользованные электролизомъ.

1) У 48-лътней жевщины авторомъ была удалева надвлагалищною гистеректоміею фиброма матки, существовавшая уже 6 льььь. Въсъ опухоли равнялся 20 фунтамъ; размжры ея: передне-задняя окружность $=23^{1} / 2$ дюймамъ, поперечвая $=22^{3} / 4$ д., діаметръ отъ ножки до верпины $=13$ д., попереqный діаметръ $=12$, а вертикальный $9^{1 / 2}$ д. Микроскопъ показалъ преобладавіе фиброзной ткани; жногочисленныя лимфатическія пространства были вышолвевы фибриномъ.

Полвое выздоровленіе.

2) Другой случай такой же операціи фпбро-кисто-міомы вм'љъ такой же благопріятвый для паціевтки исходъ.

И ваконецъ третій случай оперированной авторомъ фибро-кисто-міомы матки кончился летально, по мнъвію автора, всльдсствіе септическаго зараженія (вскрытіе не было дозволево).

Сопоставляя эти три случая съ подобными же случаями маточныхъ фибромъ, пользованныхъ другими способами, авторъ приходитъ къ слЊдующимъ выводамъ:

Эрготивъ per os или подкожно, быть можетъ, въ состояніи нъскколько замедлить или шріостановить рость опухоли.

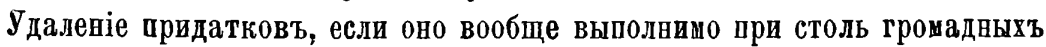
опухоляхъ, имъетъ или очень ничтожное вліяніе ва опухоль или даже викакого.

Электричество, которымъ за посльвдніе два года авторъ увлекался, не оправдало его надеждъ. Внугриматочный электродъ или уколъ опухоли товкищъ платиновым электродощъ можеть поднять и улучмить общее состояніе паціентки, остановить кровотечевія и облегчить боли, во никогда автору не удавалось этимъ способомъ привести опухоль къ обратному развитію или даже только остановить рость ея.

Между тъиъ авторъ въ своей практик' имбль случай перитонита всльдствіе прокола большого фиброида чрезъ брюшныя стьвки, а въ практикь другого врача овъ видъ̆лъ случай септическаго заражевія всль'дствіе введенія внутриматочнаго электрода.

Въ двухъ случаях'ъ автора 50 и 80 сеавсов'ъ электролиза дали улучшеніе общаго состоянія и въ однощъ изъ нихъ оставовку кровотеченій, во не им'ьли зам'ьтнаго вліянія на самую опухоль. 
Наконецъ авторъ упоминаетъ объ одномъ случаъ, удобномъ для электризаціи и для наблюденія за ростомъ опухоли, гдъ фиброидъ передней губы cervicis, величиною с'ъ горопину, не смотря на 25-кратное прим'невіе электролиза, утроился въ величин'ь.

Вообще льченіе электричествомъ такихъ опухолей совершенно не оправдало слишкомъ свътлыхъ надеждъ автора. Способъ этоть, имъющій болье дурныхъ, чынъ хорошихъ сторонъ, можетъ теперь уже сдълаться достояніешъ исторіп, какъ вышедшій почти изъ употребленія. Все то-же авторъ относитъ и но всызъ другимъ такъ вазываемымъ консервативнымъ способамъ ль̆qевія, воторые, не принося никакой существенвой пользы, самимъ выжиданіемъ подвергаютъ большой опасности одержимыхъ фиброидами, кистами яичниковъ, pyo-salpingit'ами и т. ІІ.

Ф. Кюнъ.

\section{Walker. Papillomatous cystoma of the ovary, with report of a case.} (Journ. of. the Amer. Med. Assoc. June 20, 1891 г.). Случай папилломатозной кисты яичника.

Mrs. M. R. Н. 44 лтьъъ, вдова, мать троихъ дьтей; пользовалась отличнымъ здоровьенъ до первыхъ родовъ, 24 года тому назадъ. Съ тьвхъ поръ стала жаловаться на боль въ матк' и въ яичникахъ. Посль' перенесенной 8 льттъ тому назадъ тифозной лихорадки боли усилились и распространились на весь животь и поясниду. Изсльдовавшіе ее разновременно петыре врача посл官довательно нашли слъдующее: разрывъ пейки; endocervicitis; опухоль въ л'ъвой сторов' живота; фиброна. Наконецъ въ одномъ изъ госпиталей діагвосцировали злокачественную опухоль, находящуюся въ связи съ печевью (?). Выпавпую изъ влагалища массу въ этомъ американскощъ госпиталь вправить не могли и ограничились легкими слабительными.

При изсл'дованіи авторомъ въ февраль 1891 г. найдено: паціентка презвычайно худа и изнурена; животъ увеличенъ, какъ при водянкъ. Матка и задній cul-de-sac выставлялись изъ влагалища, образуя иассу съ дытскую головку. Выпавшая масса была авторомъ безъ труда вправлена и удерживалась въ своемъ положеніи большимъ тампономъ и Т-ообразной повязкой. Убъдивпись въ томъ, что опухоль находится въ связи съ маткою, а вовсе не съ печенью, авторъ предложиль эксплораторную лапаротомію, которая и была имь произведена 12 февраля 1891 г. По вскрытіи брюпины, изъ брюпной полости было удалено около 3 галлоновъ водяночной жидкости, посль чего ясно обваружилась большая опухоль льваго яичника, захватившая и л'ъвыя трубу и широкую связку. Захвативъ всъ вытеназванныя части щипцами (ovarian forcep) близъ рога матки, авторъ отрьзаль ихъ ножомъ. ПІирокая ножка была прижжева и перевязана. Туалеть брюшины; закрытіе брютной раны.

Посльопераціовное теченіе протекло безъ особыхъ осложвевій. Паціевтка встала съ постели на 21-й девь. Мъсячныя появились правильно; матка занимала правильное положевіе и лить ньссколько откловева вльво. Больная 